\title{
Determination of Fisheries Distribution Centers
}

\author{
Setijadi \\ Department of Industrial Engineering, Widyatama University, Indonesia
}

Copyright $\bigcirc 2019$ by authors, all rights reserved. Authors agree that this article remains permanently open access under the terms of the Creative Commons Attribution License 4.0 International License

\begin{abstract}
Indonesian fisheries production in 2014 reached 20.72 million tons, consisting of capture fisheries production of 6.72 million tons and aquaculture production of 14.52 million tons. Fish distribution centers are very dependent on the support of the surrounding production areas, especially in the aspects of supply and demand. The distribution center acts as a counterweight to the supply chain system. The distribution center will serve the surrounding areas so that the availability of storage and transportation infrastructure is very necessary to ensure the availability of fish supplies at a stable price for consumers. The study produced recommendations for distribution centers, namely: Medan City, Kab. Anambas, Kab. Indramayu, Kab. Pati, Surabaya City, Mataram City, Kab. Banggai, Makassar City, Bitung City, Ambon City. Sorong City, and Tual City.
\end{abstract}

Keywords Distribution Center, Fish Logistics, Supply Chain

\section{Introduction}

Marine and fisheries resources, besides being potential as the main driver of the national economy, are also the main food sources that are intended as food or drinks for human consumption. Based on FAO data (2014), in 2012 Indonesia was ranked 2nd for capture fisheries production and ranked 4th for aquaculture production in the world.

Fisheries production in 2014 reached 20.72 million tons, consisting of capture fisheries production of 6.72 million tons and aquaculture production of 14.52 million tons (including seaweed).

This fact can provide an illustration that Indonesia's fisheries potential is very large, so that if managed properly and responsibly so that its activities can be sustainable, it can become one of the main sources of development in the present and the future.

In order to guarantee the procurement, storage, transportation and distribution of fish and fishery products for the consumption needs of the community and the fish processing industry, the Minister of Marine and Fisheries stipulates Regulation of the Minister of Marine and
Fisheries of the Republic of Indonesia Number 5 / Permen-KP / 2014 concerning Logistics Systems National Fish (SLIN). SLIN is a fish supply chain management system and fisheries products as well as information ranging from procurement, storage, transportation to distribution, as a unity of policies to increase capacity and stabilize the upstream-downstream fisheries production system, control disparity and price stabilization, and to meet the needs domestic consumption. SLIN management is at the production center and / or collection center and distribution center.

The distribution center acts as a counterweight to the existing supply chain system so that it is expected that the purchase price at the producer level will increase and the selling price at the consumer level is more stable. The success of a fish distribution center is very dependent on the support of the surrounding production areas, especially in the aspects of supply and demand. This is because the distribution center will serve the surrounding areas so that the availability of storage and transportation infrastructure is very necessary to ensure the availability of fish supply at a stable price for consumers.

In this regard, it is necessary to study the Analysis of Fisheries Distribution Centers in 20 locations. The results of this study will be used as material for government input in developing policies for supporting facilities and infrastructure for fish availability in production centers and distribution centers.

\section{The Method to Locating Distribution Center}

Determination of the distribution center location is carried out using analysis criteria consisting of: the depth of the port pool, the production volume of the district / city, the provincial production volume, and the installed capacity of the Fish Processing Unit (UPI).

The next step is the analysis phase, which consists of: identifying the analysis criteria, determining the analysis criteria / parameters to be used, determining the parameter weight, determining the parameter value interval, determining the score, determining the value, and drawing conclusions and recommendations. 


\section{Analysis of the Location of Distribution Center}

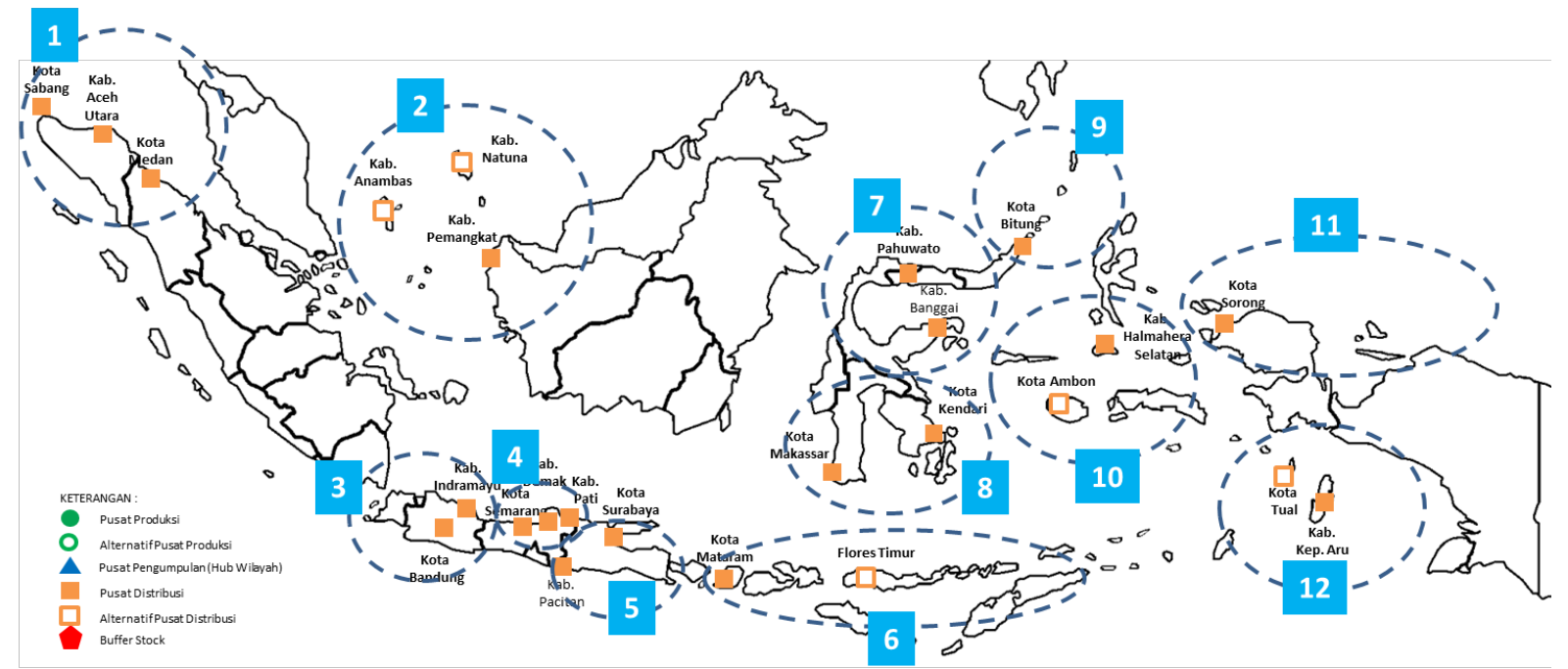

Figure 1. Criteria and principles of proposed analysis location of distribution centers

For distribution center criteria seen from several points, including:

- Location in the consumption area (community \& industry).

- Distribution centers can be located near the production center.

- Receive supplies from several production centers

- $\quad$ Serving several consumption centers (UPI).

- Volume needs at high locations.

- Adequate transportation infrastructure available (ports, highways, etc.)

The principles of distribution center analysis include:

- Analysis of proposed distribution center locations is done by grouping adjacent distribution center locations (clustering).

- For an area where there is only one proposal or alternative distribution center location, the analysis is also carried out on several locations outside of the proposal given.

As for some criteria for assessing the location of production and distribution centers, include:

Criterion 1. Port

\begin{tabular}{|c|c|c|l|}
\hline Parameter & Interval & Score & Explanation of Parameter Interval Determination \\
\hline & $<6 \mathrm{~m}$ & 2 & \\
Pool depth & $6-9 \mathrm{~m}$ & 4 & Determination of interval based on the depth of the local port pool between the highest and \\
(draft) & $9-12 \mathrm{~m}$ & 6 & lowest \\
& $12-15 \mathrm{~m}$ & 8 & \\
& $>15 \mathrm{~m}$ & 10 & \\
\hline
\end{tabular}

Criterion 2. Produksi

\begin{tabular}{|c|c|c|c|}
\hline Parameter & Interval & Score & Explanation of Parameter Interval Determination \\
\hline District/ City Consumption. & $\begin{array}{c}<30.000 \\
30.000-60.000 \\
60.000-90.000 \\
90.000-120.000 \\
>120.000\end{array}$ & $\begin{array}{c}2 \\
4 \\
6 \\
8 \\
10\end{array}$ & $\begin{array}{l}\text { Determination of intervals based on the highest and lowest } \\
\text { number of production City / District. }\end{array}$ \\
\hline Provincial Production & $\begin{array}{c}<200.000 \\
200.000-300.000 \\
300.000-400.000 \\
400.000-500.000 \\
>500.000\end{array}$ & $\begin{array}{c}2 \\
4 \\
6 \\
8 \\
10\end{array}$ & $\begin{array}{l}\text { Determination of intervals based on the highest and lowest } \\
\text { production amounts of the Province. }\end{array}$ \\
\hline
\end{tabular}


Criterion 3. Konsumsi

\begin{tabular}{|c|c|c|c|}
\hline Parameter & $\begin{array}{c}\text { Interval } \\
\text { (kg/kapita/year) }\end{array}$ & Score & Explanation of Parameter Interval Determination \\
\hline \multirow{3}{*}{ District/ City Consumption } & $<20$ & 2 & \\
& $20-40$ & 4 & Determination of intervals based on the level of \\
& $40-60$ & 6 & consumption of fish from the highest and lowest cities. \\
& $60-80$ & 8 & \\
\hline
\end{tabular}

Criterion 4. UPI (Kapasitas Fasilitas Perikanan)

\begin{tabular}{|c|c|c|c|}
\hline Para-meter & $\begin{array}{c}\text { Interval } \\
\text { (ton/year) }\end{array}$ & Score & Explanation of Parameter Interval Determination \\
\hline & $<120.000$ & 2 & \\
Pro-vince & $120.000-240.000$ & 6 & Determination of intervals based on the installed capacity \\
& $240.000-360.000$ & 8 & of the province's highest and lowest fish UPI. \\
& $360.000-480.000$ & $>480.000$ & \\
\hline
\end{tabular}

\section{Cluster Analysis 1}

Based on the three proposed production centers (Sabang City, North Aceh District, and Medan City), the most suitable as a distribution center is Medan City.

Reason:

- $\quad$ Based on the production data of the province, the production of Prov. North Sumatra 484,313 tons (score $=8$ ) is much higher than Prov. Aceh 157,944 tons $($ score $=2)$

- $\quad$ Based on production data per region, Medan City has 104,289 tons (score $=8$ ) far higher than Sabang City 7,339 tons (score $=2$ ) and production data of Kab. Aceh Utara 11,526 tons ( score $=2$ )

- Based on Medan City consumption data of $35.25 \mathrm{~kg} /$ capita / year $($ score $=4)$

- UPI installed capacity in North Sumatra Province 97,320 tons $($ score $=2$ )

- Ports in Medan City, namely Belawan, are more modern and serve containers for domestic \& export / import purposes. Belawan Port connects the city of Medan with Indonesia's major cities and several neighboring countries

\section{Cluster Analysis 2}

Based on the three proposed production centers (Pemangkat, Natuna, and Anambas Districts), the most suitable as a distribution center is Kab. Anambas.

Reason:

- Based on the province's production data, the production of Riau Islands Province is 139,331 tons $($ score $=2)$

- $\quad$ Based on production data per region, production of Kab. Anambas 21,940 tons (score $=2$ )

- $\quad$ Based on Kab. Consumption data. Anambas $76.53 \mathrm{~kg}$ / capita / year $($ score $=8)$ is higher than Natuna 53.25 $\mathrm{kg} /$ capita / year $($ score $=6)$ and Kab. Lifters 35.12 $\mathrm{kg} /$ capita / yr $($ score $=4)$
- UPI installed capacity in Kep Province. Riau 10,080 tons $($ score $=2)$

- Have Sei Kolak Kijang Port which has adequate facilities as a port for fishery distribution centers.

\section{Cluster Analysis 3}

Based on the two proposed distribution centers (Indramayu District, and Bandung), the most suitable as a distribution center is Kab. Indramayu.

Reason:

- Based on the provincial production data, the production of West Java Province is 206,156 tons $($ score $=4)$

- $\quad$ Based on production data per region, production of Kab. Indramayu 126,784 tons $($ score $=10)$

- $\quad$ Based on Kab. consumption data. Indramayu 23.17 $\mathrm{kg} /$ capita / yr ( score $=2)$

- UPI installed capacity in West Java Province 94,030 tons $($ score $=2)$

- $\quad$ The fish processing industry in West Java Province is mostly around Kab. Indramayu, Cirebon and surrounding areas.

\section{Cluster Analysis 4}

Based on the three proposed distribution centers (Semarang, Kab. Pati, and Kab. Demak), the most suitable as a distribution center is Kab. Starch.

Reason:

- Based on the province's production data, the production of Central Java Province 242,072 tons $($ score $=4)$

- Based on production data per region, production of Kab. Pati 22,585 tons ( score $=2$ )

- Based on Kab. consumption data. Pati 27.40 kg / capita / yr $($ score $=4)$

- UPI installed capacity in Central Java Province 2,400 $($ score $=2)$ 
- Having Tanjung Mas Port which can connect with the surrounding ports

- Semarang borders the Java Sea in the north, Demak Regency in the east, Semarang Regency in the south, and Kendal Regency in the west.

\section{Cluster Analysis 5}

Based on the two proposals in East Java, Pacitan Regency is more suitable as a production center compared to Surabaya

Reason:

- Based on the province's production data, the production of East Java province is 385,878 tons (score $=6$ ), higher than the production in Central Java which is 242,072 tons (score $=4$ ) and Prov. West Java 206,156 tons (score $=4$ ).

- Based on production data per region, production data of Kab. Pacitan 8,000 tons (score $=2$ ) higher than Surabaya City 7,803 tons (score $=2$ )

- Based on the City of Surabaya consumption data $24.50 \mathrm{~kg} /$ capita $/$ year $($ score $=2)$

- UPI installed capacity in East Java Province 578,650 tons $($ score $=10)$

- Owning the Tanjung Perak Port, which is famous for export / import trade, container services, and passengers. (can distribute to a number of Indonesian port cities)

- Located on the north coast of East Java province, the territory borders the Madura Strait to the north and east.

\section{Cluster Analysis 6}

Based on the two proposed distribution centers (Mataram City and East Flores Regency), the most suitable as a distribution center was Mataram City.

Reason:

- Based on the provincial production data, the production of West Nusa Tenggara Province is 227,084 ton $($ score $=4$ ), higher than production in Prov. East Nusa Tenggara 111,415 tons (score $=2$ )

- Based on production data per region, the city of Mataram produced 1,673 tons ( score $=2$ )

- Based on consumption data of Mataram City 27.03 $\mathrm{kg} /$ capita $/$ year $($ score $=4)$

- The installed capacity of UPI in NTB Province is 40,860 tons (score $=2$ )

- Has a Large Port, Gili Mas Port to accommodate large ships (can distribute to a number of regions in Nusa Tenggara).

\section{Cluster Analysis 7}

Based on the two proposed distribution centers (Kab. Pahuwato and Kab. Banggai), the most suitable as a distribution center was Kab. Banggai.
Reason:

- Based on the province's production data, the production of Central Sulawesi Province is 263,887 tons (score $=4$ ), higher than Production in Gorontalo Province 102,534 tons (score $=2$ )

- Based on production data per region, production of Kab. Banggai 21,094 tons (score = 2), higher than the production data of Kab. Pahuwato 16.604 tons $($ score $=2)$.

- District consumption data. Banggai $36.91 \mathrm{~kg} /$ capita / yr $($ score $=4)$

- UPI installed capacity in Central Sulawesi Province 5,100 tons $($ score $=2)$

- Have more than one public port, and one of them can be visited by a 600 -liter boat and a 1000 DWT berth.

\section{Cluster Analysis 8}

Based on the two proposed production centers (Makassar and Kendari), the most suitable as a production center is Makassar City.

Reason:

- Based on production data, the production of South Sulawesi Province was 287,897ton (score $=4$ ) higher than production in Southeast Sulawesi Province which was 150,588 tons ( $($ core $=2$ ).

- Based on production data per region, the production of Makassar City is 12,481 tons (score $=2$ )

- Based on Makassar City consumption data $39.10 \mathrm{~kg} /$ capita $/$ year $($ score $=4)$

- UPI installed capacity in South Sulawesi Province 7,800 tons (score $=2$ )

- Having the Soekarno-Hatta Port of Makassar, which has 6 docks, Container Terminal services, domestic $\&$ export / import (connecting the city of Makassar with Indonesia's major cities and several neighboring countries)

\section{Cluster Analysis 9}

Bitung as a distribution center

Reason:

- Based on provincial production data, North Sulawesi Province's production is 295,204 tons (score $=4$ ), higher than production in Central Sulawesi Province 263,887 tons $($ score $=4$ ), South Sulawesi 287,897 tons $($ score $=4)$, and Southeast Sulawesi 150,588 tons $($ score $=2)$

- Based on production data per region, Bitung City's production is 142,627 tons (score $=10$ )

- Based on the consumption data of Bitung City 49.10 $\mathrm{kg} /$ capita / year $($ score $=6)$

- The installed capacity of UPI in North Sulawesi Province is 380,878 tons (score $=8$ )

- Has a Bitung Port which consists of a passenger port and container port, and is the only port in North 
Sulawesi that is visited and anchored by passenger ships between major cities in Indonesia and International (International East Gate)

\section{Cluster Analysis 10}

Based on the two proposed distribution centers (Ambon and South Halmahera), the most suitable as a distribution center is Ambon City.

Reason:

- Based on the province's production data, the production of Maluku Province 538.121 ton (score = 2 ) is higher than the production of North Maluku Province 218,097 tons (score $=2$ ).

- Based on production data per region, Ambon City's production of 150,211 tons (score $=10$ ) is higher than the production of Kab. South Halmahera 48,059 tons (score $=4$ ).

- Ambon City consumption data of $50.56 \mathrm{~kg} /$ capita / year $($ score $=6)$

- UPI installed capacity in Maluku Province 95,940 tons $($ score $=2$ )

- Maluku Province as National Fish Barn 2030, consideration of the stipulation that Maluku Province is a maritime archipelago in the archipelago and potential fisheries resources

- Have an Nusantara Fishing Port (VAT)

Cluster Analysis 11

Sorong as a distribution center

Reason:

- Based on the province's data, the production of West Papua Province is 119,984 tons ( $($ core $=2$ )

- Based on production data per region, the production of Sorong City is 37,561 tons (score $=4$ ).

- Based on consumption data of Sorong City $42.91 \mathrm{~kg}$ / capita / year $($ score $=6)$

- UPI installed capacity in West Papua Province 84,100 tons $($ score $=2$ )

- Have a public port that has a capacity of Pier I $(1,440$ $\mathrm{T} / \mathrm{m} 2)$ and Pier I \& II $(1,760 \mathrm{~T} / \mathrm{m} 2)$

- Strategic location because it is the entrance and transit door to West Papua Province

\section{Cluster Analysis 12}

Based on the two proposed distribution centers (Aru and Tual Islands), the most suitable as a distribution center is the City of Tual.

Reason:

- Based on the province's production data, the production of Maluku Province 538.121ton (score = 10)

- Based on production data per region, Tual City's production is 32,277 tons (score $=4$ )
- Based on Tual City consumption data $40.48 \mathrm{~kg} /$ capita / yr $($ score $=6)$

- UPI installed capacity in Maluku Province 95,940 tons ( score $=2$ )

- Have a common type of port that can serve export movements, and connect with other ports in Indonesia.

\section{Conclusions}

Choosing the fisheries hub location considers several characteristics of certain locations.

A summary of the determination of the distribution center location is shown in the following table:

\begin{tabular}{|c|c|c|}
\hline Cluster & $\begin{array}{l}\text { Proposed Location of } \\
\text { the Distribution Center }\end{array}$ & $\begin{array}{l}\text { Distribution Center } \\
\text { Recommendations }\end{array}$ \\
\hline \multirow{3}{*}{1} & Kota Sabang & \multirow{3}{*}{ Kota Medan } \\
\hline & Kab. Aceh Utara & \\
\hline & Kota Medan & \\
\hline \multirow{3}{*}{2} & Kab. Pemangkat & \multirow{3}{*}{ Kab. Anambas } \\
\hline & Kab. Natuna & \\
\hline & Kab. Anambas & \\
\hline \multirow{2}{*}{3} & Kota Bandung & \multirow{2}{*}{ Kab. Indramayu } \\
\hline & Kab. Indramayu & \\
\hline \multirow{3}{*}{4} & Kota Semarang & \multirow{3}{*}{ Kab. Pati } \\
\hline & Kab. Demak & \\
\hline & Kab. Pati & \\
\hline \multirow[b]{2}{*}{5} & Kota Surabaya & \multirow{2}{*}{ Kota Surabaya } \\
\hline & Kab. Pacitan & \\
\hline \multirow[b]{2}{*}{6} & Kota Mataram & \multirow{2}{*}{ Kota Mataram } \\
\hline & Kab. Flores Timur & \\
\hline \multirow{2}{*}{7} & Kab. Pahuwato & \multirow{2}{*}{ Kab. Banggai } \\
\hline & Kab. Banggai & \\
\hline \multirow{2}{*}{8} & Kota Makassar & \multirow{2}{*}{ Kota Makassar } \\
\hline & Kota Kendari & \\
\hline 9 & Kota Bitung & Kota Bitung \\
\hline \multirow{2}{*}{10} & Kab. Halmahera Selatan & \multirow{2}{*}{ Kota Ambon } \\
\hline & Kota Ambon & \\
\hline 11 & Kota Sorong & Kota Sorong \\
\hline \multirow{2}{*}{12} & Kab. Kep Aru & \multirow{2}{*}{ Kota Tual } \\
\hline & Kota Tual & \\
\hline
\end{tabular}

Thus, the distribution center recommendations are: Medan City, Kab. Anambas, Kab. Indramayu, Kab. Pati, Surabaya City, Mataram City, Kab. Banggai, Makassar 
City, Bitung City, Ambon City. Sorong City, and Tual City.

The recommendations and policy implications of this study are:

(1) Improvement of port infrastructure and facilities in accordance with the needs of production centers and distribution centers, mainly including pond depth and dock length (according to vessel size, frequency, etc.) and port infrastructure for handling fish catches, especially cold storage;

(2) Increasing logistical services: increasing cooperation with logistics service providers;

(3) Highway access, including increasing road access between ports, location of production centers and distribution centers, and location of fish processing industries;

(4) Land: provision of sufficient land at the port and location of production centers and distribution centers;

(5) Supporting infrastructure, including increasing availability of electricity at ports and locations of production centers and distribution centers, as well as increasing availability of clean water in ports and locations of production centers and distribution centers.

\section{REFERENCES}

[1] Quebec, "The Marine Product Processing Act," 1 April 2006. [Online]. Available: http://legisquebec.gouv.qc.ca/en/show doc/cs/T-11.01/20060401. [Accessed 20 February 2017].

[2] The World Bank, "Oceans, Fisheries and Coastal Economies," The World Bank, 3 October 2016. [Online]. Available:

http://www.worldbank.org/en/topic/environment/brief/ocea ns. [Accessed 20 February 2017].

[3] FAO, "The State of World FIsheries and Aquaculture Production," FAO, Rome, 2014.

[4] C. G. Nicolae, L. M. Moga, M. I. Nenciu, G. V. Bahaciu and M. P. Marin, "PARTICULARITIES AND MANAGEMENT OF THE DISTRIBUTION CHAIN FOR FISH AND FISHERY PRODUCTS," Agro Life Scientific Journal, vol. 4, no. 1, pp. 111-116, 2015.

[5] I. Metaxa, " Asigurarea și controlul calităţii în acvacultură " Bucharest, 2003.

[6] The World Bank, "Fisheries capture production," The World Bank, 31 December 2015. [Online]. Available: http://data.worldbank.org/indicator/ER.FSH.CAPT.MT. [Accessed 1 February 2016].

[7] FAO, "The State of World Fisheries and Aquaculture," FAO, Rome, 2016.

[8] CEA, "Indonesia Fisheries: 2015 Review," California Environmental Associate, 31 December 2016. [Online]. Available: https://www.packard.org/wp-content/uploads/2016/09/Indo nesia-Fisheries-2015-Review.pdf. [Accessed 1 February
2017].

[9] Sabir, F. K., \& Sabir, A. (2018). Effects of Different Storage Conditions on Rooting and Shooting Performance of Grapevine (Vitis Vinifera L.) Cuttings in Hydroponic Culture System. International Journal of Sustainable Agricultural Research, 5(3), 46-53.

[10] Ghosh, A. K. (2018). Sphene and Zircon Fission Track Analysis of Syenite Rocks of the Sushina Hills, Purulia-Bankura Shear Zone (TPSZ). International Journal of Geography and Geology, 7(4), 73-79.

[11] Supply Chain Indonesia, "Cold Chain System untuk Peningkatan Efesiensi dan Produktivitas Sektor Perikanan," 26 January 2015. [Online]. Available: http://supplychainindonesia.com/new/cold-chain-system-un tuk-peningkatan-efesiensi-dan-produktivitas-sektor-perikan an/. [Accessed 20 February 2017].

[12] Setijadi, "Ringkasan Eksekutif Kajian Pusat Produksi dan Pusat Distribusi," Supply Chain Indonesia, Bandung, 2016.

[13] Mofokeng, M. A., \& Mashingaidze, K. (2018). Genetic Differentiation of ARC Soybean [Glycine Max (L.) Merrill] Accessions Based on Agronomic and Nutritional Quality Traits. Agriculture and Food Sciences Research, 5(1), 6-22.

[14] Ubua, J. A., Ozung, P. O., Inagu, P. G., \& Aboluja, B. A. (2018). Blood Characteristics of Broiler Chickens as Influenced by Dietary Inclusion of Neem (Azadirachta indica) Leaf Meal. Canadian Journal of Agriculture and Crops, 3(2), 72-80.

[15] Bloomberg, "Fish Farming Becomes Bigger Business than the Open Sea," 18 August 2015. [Online]. Available: https://www.bloomberg.com/news/articles/2015-08-17/hun gry-fish-farms-lure-cargill-as-seafood-demand-grows. [Accessed 1 February 2017]. 